IRA-International Journal of Applied Sciences ISSN 2455-4499; Vol.07, Issue 02 (2017)

Institute of Research Advances

Pg. no. 62-68

http://research-advances.org/index.php/IRAJAS

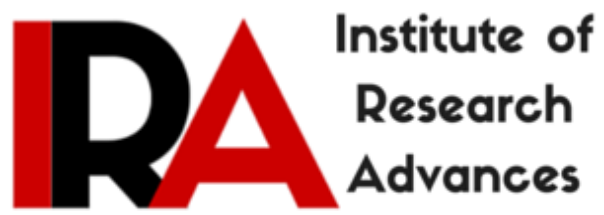

\title{
Dissipation Behavior of a Mancozeb Residue (Dithiocarbamate Fungicide) in Tomato Under South Moroccan Climatic Condition
}

\section{El Habib Ait Addi}

Engineering and Chemical Engineering Group, High School of Technology, University Ibn Zohr, B.P: 33/S, Agadir 80000, Morocco.

Type of Review: Peer Reviewed.

DOI: http://dx.doi.org/10.21013/jas.v7.n2.p2

\section{How to cite this paper:}

Addi, E. (2017). Dissipation Behavior of a Mancozeb Residue (Dithiocarbamate Fungicide) in Tomato Under South Moroccan Climatic Condition. IRA-International Journal of Applied Sciences (ISSN 2455-4499), 7(2), 62-68. doi:http://dx.doi.org/10.21013/jas.v7.n2.p2

(C) Institute of Research Advances

\section{$(\mathrm{cc}) \mathrm{BY}-\mathrm{NC}$}

This work is licensed under a Creative Commons Attribution-Non Commercial 4.0 International License subject to proper citation to the publication source of the work.

Disclaimer: The scholarly papers as reviewed and published by the Institute of Research Advances (IRA) are the views and opinions of their respective authors and are not the views or opinions of the IRA. The IRA disclaims of any harm or loss caused due to the published content to any party. 


\begin{abstract}
Dissipation behavior of mancozeb, a widely used dithiocarbamte fungicide, applied under field condition on tomato at recommended dose was undertaken under greenhouses and open field during October and March in Souss-Massa area (south of Morocco) climatic condition. Residue levels of mancozeb were determined by using a simple method consisting in a hot acid digestion of the whole sample to evolve carbon disulfide $\left(C S_{2}\right)$, which is further quantified by spectrophotometry. Degradation rate in both open field and greenhouse followed first order kinetic. Half lives were 1.77 and 1.3 days in open field and in greenhouse were 2.0 and 1.8 days for October and March period respectively. Based on the observation reported, a pre harvested interval of at least three days after pesticide application at recommended dose may be suggested.
\end{abstract}

Key words: Mancozeb, Dissipation, Tomato, Souss-Massa

\title{
1. INTRODUCTION
}

In Morocco, tomatoes are considered to be high value cash crops for farmers and they are also a source of hard currency. The annual production of these crops is over 600000 tons, of which about $80 \%$ is exported from Souss-Massa area.

Long-cycle tomatoes grown develop throughout autumn and part of spring. Fruits ripen gradually and are usually harvested weekly. Therefore, to protect tomato from pathogens, such as grey mold, pesticides with a short pre-harvest interval (PHI) of one week or less are required. Conventional fungicides have shown resistance phenomena due to their extensive use [1,2]. As a result, these compounds do not give sufficient protection and the PHI of most of these pesticides is too long.

Dithiocarbamate, a non-systemic group of pesticide, is one of the major fungicide groups used in the production of agricultural crops and the most frequently detected pesticides in food monitoring programs in many countries [3-7]. In addition, Fungicides of the dithiocarbamate group are much better at controlling fungal pathogens of Solanaceous crops and vegetables [8]. To sustain the quality and productivity of the crops mancozeb, the ethylene-bis-dithiocarbamate (EBDC), is recommended but it was considered to be a multipotent carcinogenic agent in a long-term rat study [9].

The methodology most commonly used by monitoring laboratories to analyze dithiocarbamates in natural food products relies on the detection of $\mathrm{CS}_{2}$ generated after acid digestion of any dithiocarbamates present in the crop [3-7]. Spectrophotometry [10-11] or gas chromatography [12-14] can be used for detection of these compounds, but the origin of the $\mathrm{CS}_{2}$ generated cannot be determined by these methods.

With the intensive use of pesticides, residues may be accumulated at levels higher than those permitted by the EU or international MRLs. The dissipation rate of a pesticide after application is a useful tool for the assessment of the behaviour of its residues. Additionally, residues dissipation curves can be used to estimate the time required for decreasing the residues levels below MRLs [1517]. To the best of our knowledge, there is limited data in the literature concerning the dissipation rate of the mancozeb in tomato.

Tomato crop is highly remunerative and sprayed heavily with fungicides close to harvest, which may leave harmful residues in fruits. The present investigation was conducted to determine the dissipation pattern as well as the residue level of Mancozeb, when applied recommended doses, in tomatoes fruits in two different growing locations: under greenhouses and in open field during two periods: October and March under Souss-Massa area (south of Morocco) climatic conditions.

\section{MATERIALS AND METHODS}

\section{Chemicals}

In the present study, Mancozeb, an analytical standard purity $98.97 \%$, was purchased from Sigma Aldrich and the carbon disulfide $\mathrm{CS}_{2}$ was purchased from Fluka, Swisserland. 
Commercial mancozeb (Ditham M45) was purchased from local distributors.

Hydrochloric acid, Potassium iodide, Tin (II) chloride, Sodium hydroxide, diethanolamine, ethanol and cupric acetate monohydrate were purchased from Panreac, Spain.

\section{Design of Field Experiment}

The study was carried out at orchard located in the Souss-Massa area (south of Morocco). Four field experiments were conducted to study the residues of Mancozeb in Tomatoes fruits.

The first trial was conducted under greenhouse (Location-I) with Tomatoes. On the contrary, the second trial was conducted in open field (Location-II) with the same variety. The trials were conducted during October (Period-I) and during March (Period-II) at both location. The tomatoes varieties were sown with a spacing of $40 \mathrm{~cm} \times 100 \mathrm{~cm}$ and the plot size was $9 \mathrm{~m} \times 9 \mathrm{~m}\left(81 \mathrm{~m}^{2}\right)$ in open field. However, under greenhouse the tomato planting density was 20000 plants/ha.

\section{Application of Fungicides}

The treatment was carried out with Ditham M45 (Mancozeb 80\%) as a commercial formulation applied at the dose recommended by the manufacturer $(200 \mathrm{~g} / \mathrm{hL})$ with a portable motor sprayer. The pesticide was applied as a single application only. Identical portions of trees were maintained as controls.

\section{Collection of Samples}

Fruits of Tomato were collected randomly at intervals of 0 ( 2 hrs after application), 1, 3, 5, 7, 9, 14, 15, 16 days after spraying with pesticide. Each sample consisted of 10 pieces of tomatoes. The samples were collected, sealed in labelled polyethylene bags with a unique sample identity, stored at 4 ${ }^{\circ} \mathrm{C}$ and transported to the laboratory. The samples were deep-frozen until analysis was carried out.

\section{Extraction and Clean up}

The digestion/distillation apparatus was used for the determination of $\mathrm{CS}_{2}$ from residues of dithiocarbamate fungicides. The Representative $100 \mathrm{~g}$ sample of crop matrices, with $10 \mathrm{~g}$ of KI, $2 \mathrm{~g}$ of $\mathrm{SnCl} 2$ and $200 \mathrm{ml}$ of distilled water, were decomposed by refluxing with dilute acid $(30 \mathrm{~mL}$ hydrochloric acid). Released $\mathrm{CS}_{2}$ is pushed through the entire system by applying slight vacuum. The evolved $\mathrm{CS}_{2}$ was trapped in trap containing $10 \mathrm{~mL}$ of $15 \% \mathrm{NaOH}$ solution. The final $\mathrm{CS}_{2}$ trap contained $15 \mathrm{~mL}$ of Cullen reagent, made up from $25 \mathrm{mg}$ of cupric acetate monohydrate and $25 \mathrm{~g}$ diethanolamine in $250 \mathrm{ml}$ ethanol. The solution of the complex formed from the reaction between $\mathrm{CS}_{2}$ and the copper (II) acetate monohydrate was measured at $435 \mathrm{~nm}$ in a Agilent $8453 \mathrm{UV}-\mathrm{Vis}$ spectrophotometer.

\section{RESULTS AND DISCUSSION}

\section{Analytical procedure}

\section{Estimation of Residues}

The level of residues in the samples was expressed as $\mathrm{mg}$ of carbon disulfide $\left(\mathrm{CS}_{2}\right)$ per $\mathrm{kg}$ fruits. The limit of detection (LOD) and limit of quantification (LOQ) were $0.01 \mu \mathrm{g} / \mathrm{g}$ and $0.03 \mu \mathrm{g} / \mathrm{g}$, respectively.

\section{Recovery Experiment}

In order to estimate the efficiency of the method, recovery experiment was conducted by fortifying untreated samples of Tomato fruits with Mancozeb at $0.1,0.25,0.50$ and $1 \mathrm{mg} / \mathrm{kg}$ level. The fortified samples were analyzed and estimated following the method as described earlier. Average recoveries of Mancozeb from different substrates fortified ranged from 86-94\% (Table-1).

\section{Disappearance of Mancozeb from tomatoes:}

The residue data, including mean values, standard deviations and \% dissipation obtained in the decline study after treatment of Mancozeb are summarized in Table 2 and 3.

The residue was found below the detectable limit in the untreated control. 
The results obtained shows that the initial deposits of mancozeb ( 0 days) in tomatoes fruits were found to be fairly uniform $(6.16-6.28 \mathrm{mg} / \mathrm{kg}$ ) independently of the period and the location. However, there were significant differences in the rates of dissipation not only according to the location but also according to the period. In general, by comparing the rates of dissipations we notice that residues dissipated at faster rate in the case of the open field than in the case under greenhouse. It was also observed from the study that the dissipation rate was faster in period 2 than period 1 . But, in all cases, residues were detected until the $14^{\text {th }}$ day, beyond that no residues were detected. The only exception was observed in trial carried out in period 2 at location 2, where more than $99 \%$ reduction was achieved 9 days after spraying. We note that a rainfall was happened shortly after the application during this period.

The faster rate of dissipation can be attributed to the differences in the dilution due to the growth of tomato fruits and the excessive rains. The results are comparable with other works [8,18-19].

The growth dilution factor is important in reducing the residue levels in tomato as the fruit on which pesticides are applied is in different stages of growth. The immature fruits by the time attain the size and the coloration required; the residue of applied pesticides on them will undergo a growth dilution. Xue and Chen reported that the dissipation of pyrithyroid residues had been due to growth dilution factor[20]. A rainfall shortly after the application plays a significant role in washing of applied pesticides and might be the major reason for faster dissipation of residue in period 2 at location 2 as observed in the present study [21].

Since a strong correlation co-efficient (0.9583 - 0.9927) was obtained between residue dissipation and time it was concluded that the dissipation rate followed the first order kinetics at both periods and in both locations. The reaction rate constant was calculated from the slope of the linear regression line. Following the first order reaction, the half life of adsorption could be determined from: $\mathrm{LnC} / \mathrm{Co}=-\mathrm{kt}$ where $\mathrm{Co}$ and $\mathrm{C}$ were the initial concentration and concentration of mancozeb at time $\mathrm{t}$ and $\mathrm{k}$ was the reaction rate constant.

Based on the first-order rate constants obtained, the fungicides dissipated in the following sequence (Table 4): OFP2 $\left(0.52 \mathrm{~d}^{-1}\right)>\operatorname{OFP} 1\left(0.39 \mathrm{~d}^{-1}\right)>\operatorname{GHP} 2\left(0.37 \mathrm{~d}^{-1}\right)>\operatorname{GHP} 1\left(0.34 \mathrm{~d}^{-1}\right)$.

On the basis of data generated the half-life values were calculated and found as $2.11 ; 2.28$ days at location I and 1.77; 2.03 days at location 2. The pre-harvest intervals (PHI) were also calculated at MRL of $3 \mathrm{mg} / \mathrm{kg}$ and found to be 2.21-3.0 days irrespective of periods and locations. The results are comparable with earlier studies [19,22-23].

When compared with the proposed MRL of $3.0 \mathrm{mg} / \mathrm{kg}$ on Tomato, the residues of mancozeb reached below MRL in 2.8-3.0 days and 2.21-2.69 days for location I and location-II, respectively. The preharvest intervals (PHI) of mancozeb in the present investigations are in agreement with the reports of earlier workers with values of 2.02-4.85 days for propineb in tomato [8,24].

Therefore it is recommended that Tomatoes fruits may be harvested 3 days after spraying of mancozeb at the recommended doses in accordance with good agricultural practices.

\section{REFERENCES}

[1] Cabras P, Meloni M, Piriasi FM and Cabitza F (1985 a) Behaviour of acylanilide and dicarboximidic fungicide residues on green-house tomatoes. J Agric Food Chem, 33:86-89

[2] Cabras P, Cabitza F, Meloni M and Pirisi FM (1985 b) Behaviour of some pesticide residues on green-house tomatoes. 2 - Fungicides, Acaricides and Insecticides, J Agric Food Chem, 33:935-937

[3] Dogheim, S.M., El-Marsafy, A.M., Salama, E.Y., Gadalla, S.A., Nabil,Y.M., 2002. Monitoring of pesticide residues in Egyptian fruits and vegetables during 1997. Food Additives and Contaminants 19, 1015-1027.

[4] Dogheim, S.M., Alla, S.A.G., El-Marsafy, A.M., Fahmy, S., 1999. Monitoring pesticide residues in Egyptian fruits and vegetables in 1995. Journal of AOAC International 82, 948-955. 
[5] EU, 2001. Monitoring of pesticide residues in products of plant origin in the European Union, Norway, Iceland and Liechtenstein, 2001 Report. European Commission, Health and Consumer Protection Directorate-General Directorate F-Food and Veterinary Office.

[6] Ripley, B.D., Lissemore, L.I., Leisheman, P.D., Denomme, M.A.,2000. Pesticide residues on fruits and vegetables from Ontario, Canada, 1991-1995. Journal of AOAC International 83, 196-213.

[7] PARA, 2003. Programa de Analis de Residuos de Agrotoxicos em Alimentos-Resultados Analiticos de 2002. Agencia Nacional de Vigilancia Sanitaria. Available from: $<$ http://www.anvisa.gov.br/ toxicologia/residuos/rel_anual_2002_an2.pdf>.

[8] Ahuja, A.K. and B.N. Pande. (2004). Dissipation pattern of mancozeb and Propineb residues in chilli fruits. Indian Journal of Plant Protection. 32(2): 93-95

[9] Belpoggi, F., Soffritti, M., Guarino, M., Lambertini, L., Cevolani, D., Maltoni, C., 2002. Results of long-term experimental studies on the carcinogenicity of ethylene-bis-dithiocarbamate (Mancozeb) in rats. Annals of New York Academy of Sciences 982, 123-136.

[10] Cullen, T.E., 1964. Spectrophotometric determination of dithiocarbamates residues on food crops. Analytical Chemistry 36, 221-224.

[11] Keppel, G. E. (1971) Collaborative Study of the Determination of Dithiocarbamate Residues by a Modified Carbon Disulfide Evolution Methodology. J. Assoc. Off. Anal. Chem., 54, 528-532.

[12] Hill, A.R.C.,( 1992). Headspace methods for dithiocarbamates. In: Cairns, T., Sherma, J. (Eds.), Modern Methods for PesticideAnalysis. Emerging Strategies for Pesticide Analysis. CRC Press, London, pp. 213-231.

[13] Friedrichs, K, Winkeler, H.D, Gerhards, P., 1995. Determination of dithiocarbamate residues in foodstuff by head space gas chromatography and flame photometric detection. Z. Lebensm Unters Forsh 201, 69-73.

[14] De Kok, A., van Bodegraven, P., 2000. The determination of dithiocarbamate pesticides in fruits, vegetables and cereals via iso-octane extraction of carbon disulfide and subsequent GC-ECD

[15] Castillo-Sanchez, J., Aguilera-del Real, A., Rodriguez-Sanchez, M., \& Valverde-Garcia, A. (2000). Residue levels, decline curves, and plantation distribution of procymidone in green beans grown in greenhouse. Journal of Agricultural Food and Chemistry, 48, 2991-2994.

[16] Fenoll, J., Ruiz, E., Hellín, P., Lacasa, A., \& Flores, P. (2009). Dissipation rates of insecticides and fungicides in peppers grown in greenhouse and under cold storage conditions. Food Chemistry, $113,727-732$.

[17] Lantos, J., \& Ambrus, A. (2002). Evaluation of the studies on decline of pesticide residues. Journal of Agricultural Food and Chemistry, 50, 4846-4851.

[18] Liesivuori, J. and K. Savolainen. (1994) . Dithiocarbamates. Toxicology 91: 37-42

[19] Md. Wasim Aktar, M. Paramasivam and Dwaipayan Sengupta. 2009 Degradation dynamics and dissipation kinetics of a dithiocarbamate fungicide (propineb) in potato under east-indian climatic condition. Kasetsart J. (Nat. Sci.) $43: 50$ - 55

[20] Xue, Y. Z., \& Chen, Z. M. (1992). In Y. C. Du (Ed.), Advance in the investigation on the technology of chemical control (pp. 165-170). Xinjian Science and Technology.

[21] Chen, Z. M., \& Wan, H. B. (1997). Degradation of pesticides on plant surfaces and its predictiona case study on tea plant. Environmental Monitoring Assessment, 44, 1303-1313.

[22] M.A. Sarkar, H. Banerjee, R.K. Kole, A. Chowdhury, A. Choudhury, M.D. Mohasin. Pestol. 22, 8-14 (1998).

[23] M. Omirou , Z. Vryzas ,E. Papadopoulou-Mourkidou , A. Economou ; Dissipation rates of iprodione and thiacloprid during tomato production in greenhouse Food Chemistry 116 (2009) 499504

[24] Biswas Sajal Kumar, Banerjee Kaushik and Handa Swadesh Kumar (2003). Metabolic fate of mancozeb in tomato (Lycopersicon esculentum). Toxicological and Environmental Chemistry 85(1-3): 33-38. 
Table 1. Results of method validation by recovery analysis of Mancozeb from test samples.

\begin{tabular}{|l|l|l|l|l|}
\hline Substrate & $\begin{array}{l}\text { Amount fortified } \\
(\mathrm{mg} / \mathrm{kg})\end{array}$ & $\begin{array}{l}\text { Amount } \\
\text { recovered } \\
(\mathrm{mg} / \mathrm{kg})\end{array}$ & $\begin{array}{l}\text { Recovery of } \\
\text { Mancozeb } \\
(\%)\end{array}$ & $\begin{array}{l}\text { Average recovery } \\
\text { of Mancozeb } \\
(\%)\end{array}$ \\
\hline \multirow{3}{*}{ Tomatoes } & 0.1 & 0.088 & 88 & \multirow{3}{*}{90} \\
\cline { 2 - 4 } & 0.25 & 0.22 & 88 & \\
\cline { 2 - 4 } & 0.5 & 0.48 & 90 & \\
\cline { 2 - 5 } & 1 & 0.94 & 94 & \\
\hline
\end{tabular}

Table 2. Dissipation of mancozeb in/on Tomato at Location-I: under Greenhouse ( GH)

\begin{tabular}{|c|c|c|c|c|}
\hline \multirow{2}{*}{$\begin{array}{l}\text { Sampling } \\
\text { Interval } \\
\text { (in days) }\end{array}$} & \multicolumn{2}{|l|}{$\begin{array}{l}\text { October ( Period1) } \\
\text { GHP1 }\end{array}$} & \multicolumn{2}{|l|}{$\begin{array}{l}\text { March ( Period2) } \\
\text { GHP2 }\end{array}$} \\
\hline & $\begin{array}{l}\text { Residue }(\mathrm{mg} / \mathrm{kg}) \\
\mathbf{M} \pm \mathbf{S D}\end{array}$ & \% of Dissipation & $\begin{array}{l}\text { Residue } \quad(\mathrm{mg} / \mathrm{kg}), \\
\mathbf{M} \pm \text { SD }\end{array}$ & \% of Dissipation \\
\hline 0 & $6.25 \pm 0.04$ & - & $6.28 \pm 0.06$ & - \\
\hline 1 & $4.81 \pm 0.08$ & 23.04 & $4.67 \pm 0.02$ & 25.64 \\
\hline 3 & $2.84 \pm 0.05$ & 54.56 & $2.73 \pm 0.08$ & 56.53 \\
\hline 5 & $1.52 \pm 0.09$ & 75.68 & $1.38 \pm 0.04$ & 78.03 \\
\hline 7 & $0.88 \pm 0.03$ & 85.92 & $0.56 \pm 0.07$ & 91.08 \\
\hline 9 & $0.3 \pm 0.05$ & 95.20 & $0.2 \pm 0.08$ & 96.82 \\
\hline 14 & $0.059 \pm 0.09$ & 99.06 & $0.041 \pm 0.08$ & 99.35 \\
\hline 15 & ND & - & ND & - \\
\hline 16 & ND & - & ND & - \\
\hline
\end{tabular}

ND: not detected, slimit of detection (LOD)

Table 3. Dissipation of mancozeb in/on Tomato at Location-II: Open Field ( OF)

\begin{tabular}{|c|c|c|c|c|}
\hline \multirow{2}{*}{$\begin{array}{l}\text { Sampling } \\
\text { Interval } \\
\text { (in days) }\end{array}$} & \multicolumn{2}{|l|}{$\begin{array}{l}\text { October ( Period1) } \\
\text { OFP1 }\end{array}$} & \multicolumn{2}{|l|}{$\begin{array}{l}\text { March ( Period2) } \\
\text { OFP2 }\end{array}$} \\
\hline & $\begin{array}{l}\text { Residue }(\mathrm{mg} / \mathrm{kg}) \text {, } \\
\mathbf{M}^{*} \pm \mathbf{S D}\end{array}$ & $\begin{array}{l}\text { \% } \\
\text { of Dissipation }\end{array}$ & $\begin{array}{l}\text { Residue } \quad(\mathrm{mg} / \mathrm{kg}), \\
\mathbf{M}^{*} \text {, SD }\end{array}$ & $\begin{array}{l}\text { \% } \\
\text { of Dissipation }\end{array}$ \\
\hline 0 & $6.16 \pm 0.04$ & - & $6.17 \pm 0.06$ & - \\
\hline 1 & $4.31 \pm 0.08$ & 30.03 & $3.07 \pm 0.02$ & 50.24 \\
\hline 3 & $2.48 \pm 0.05$ & 59.74 & $1.44 \pm 0.08$ & 76.66 \\
\hline 5 & $1.22 \pm 0.09$ & 80.19 & $0.52 \pm 0.04$ & 91.57 \\
\hline 7 & $0.60 \pm 0.03$ & 90.26 & $0.31 \pm 0.07$ & 94.98 \\
\hline 9 & $0.16 \pm 0.05$ & 97.40 & $0.035 \pm 0.08$ & 99.43 \\
\hline 14 & $0.031 \pm 0.09$ & 99.50 & ND & - \\
\hline 15 & ND & - & ND & - \\
\hline 16 & ND & - & ND & - \\
\hline
\end{tabular}

ND: not detected, slimit of detection (LOD) 
Table 4. Regression equation, Determination Coefficient, Degradation rate constant k, half-life and Pre-harvest interval for the dissipation of mancoczeb in Tomatoes at different Location and period.

\begin{tabular}{|c|c|c|c|c|c|}
\hline Period & Location & $\begin{array}{l}\text { Determination } \\
\text { coefficient } \\
\left(\mathrm{R}^{2}\right)\end{array}$ & $\begin{array}{l}\text { Degradation rate } \\
\text { constant k }\left(\text { days }^{-1}\right)\end{array}$ & Half life (days) & $\begin{array}{l}\text { Pre-harvest } \\
\text { interval } \\
\text { (days) }\end{array}$ \\
\hline \multirow[b]{2}{*}{ October } & $\begin{array}{l}\text { Open field } \\
\text { OFP1 }\end{array}$ & $\mathrm{R}^{2}=0.9895$ & 0.39 & 1.77 & 2.69 \\
\hline & $\begin{array}{l}\text { Green house } \\
\text { GHP1 }\end{array}$ & $\mathrm{R}^{2}=0.9914$ & 0.34 & 2.03 & 3.0 \\
\hline \multirow[b]{2}{*}{ March } & $\begin{array}{l}\text { Open field } \\
\text { OFP2 }\end{array}$ & $\mathrm{R}^{2}=0.9583$ & 0.52 & 1.33 & 2.21 \\
\hline & $\begin{array}{l}\text { Green house } \\
\text { GHP2 }\end{array}$ & $\mathrm{R}^{2}=0.9927$ & 0.37 & 1.86 & 2.8 \\
\hline
\end{tabular}

